\title{
A new species of the jumping spider genus Icius Simon, 1876 from India (Aranei: Salticidae: Chrysillini)
}

\author{
Новый вид из рода пауков-скакунчиков Icius Simon, 1876 \\ из Индии (Aranei: Salticidae: Chrysillini)
}

\author{
Dhruv A. Prajapati, ${ }^{1,2}$, Jobi J. Malamel ${ }^{1,2^{*}}$, \\ Ambalaparmbil V. Sudhikumar ${ }^{1,3}$, Pothalil A. Sebastian ${ }^{2}$ \\ Ахрув А. Праджапати ${ }^{1,2}$, Азкоби А. Маламе $\Lambda^{1,2^{*}}$, \\ Амбалапармбия В. Судхикумар 2 , Потхалим А. Себастиан ${ }^{2}$
}

\footnotetext{
${ }^{1}$ Research and Development Centre, Bharathiar University, Coimbatore - 641 014, India.

${ }^{2}$ Division of Arachnology, Department of Zoology, Sacred Heart College, Thevara, Cochin, Kerala 682013 , India

${ }^{3}$ Centre for Animal Taxonomy and Ecology, Department of Zoology, Christ College, Irinjalakuda, Kerala, 680 125, India

*Corresponding author. E-mail: jomaljoseph@yahoo.co.in
}

KEY WORDS: jumping spiders, South India, new species, taxonomy, distribution.

КЛЮЧЕВЫЕ СЛОВА: пауки-скакунчики, южная Индия, новый вид, таксономия, распространение.

ABSTRACT. A new species of the jumping spiders - Icius vikrambatrai sp.n. $\left(O^{\top}+\right)$ - is described from South India. A detailed morphological description, diagnosis and illustrations of the copulatory organs are provided. Distribution of all the Indian Icius species is mapped.

How to cite this article: Prajapati D.A., Malamel J.J., Sudhikumar A.V., Sebastian P.A. 2018. A new species of the jumping spider genus Icius Simon, 1876 from India (Aranei: Salticidae: Chrysillini) // Arthropoda Selecta. Vol.27. No.4. P.330-334. doi: 10.15298/ arthsel. 27.4.08

РЕЗЮМЕ. Новый вид пауков-скакунчиков Icius vikrambatrai sp.n. ( $\left.\sigma^{\top}+\right)$ - описан из южной Индии. Даны детальное морфологическое описание, диагноз и рисунки копулятивных органов. Распространение всех индийских видов Icius прокартировано.

\section{Introduction}

A total of 35 valid species has been known worldwide in the genus Icius Simon, 1876 [WSC, 2018], of which seven have been recorded/described from south and south-east Asia: viz., one species is known from Afghanistan, three from China, one from Indonesia and two from India. Icius alboterminus (Caleb, 2014) and I. kumariae Caleb, 2017 were recently described from both sexes from India [Caleb, 2014, 2017]. I. alboterminus was originally described in the genus Phintella Strand, in Bösenberg et Strand, 1906 and then transferred to Icius [Caleb, 2017]. In present paper we aim to describe a new species Icius vikrambatrai sp.n. $\left(\sigma^{7}+\right)$ from southern India.
Materials and methods

Samples were hand-collected. The specimens were studied by means of a LEICA S8AP0 stereomicroscope. All measurements are in mm. Length of the palp and leg segments are given as follows: total (femur, patella, tibia, metatarsus (except palp), tarsus). Spine positions are as follows: prolateral, dorsal, retrolateral and ventral. B/W drawings were made by means of a drawing apparatus attached to the LEICA microscope. Digital images were taken by a Leica DFC2900 digital camera attached to the Leica M205 A stereomicroscope with the software package Leica Application Suite (LAS), version 4.5.0. The studied specimens have been deposited in the reference collection of the Division of Arachnology, Department of Zoology, Sacred Heart College, Thevara, Cochin, Kerala, India (ADSH). Abbreviations used in the text. ALE - anterior lateral eye, AME - anterior median eye, PLE — posterior lateral eye, $\mathrm{PME}$ - posterior median eye, I-IV — 1st to 4 th legs.

\section{Taxonomy}

Icius Simon, 1876

Type species: Icius hamatus C.L. Koch, 1846.

Diagnosis. For diagnostic features and description of the genus see Alicata \& Cantarella [1994].

\section{Icius vikrambatrai sp.n.}

Figs 1-17, Map.

TYPES: Holotype male (ADSH872381) from India, Kerala, Alappuzha, Pathiramanal Island $\left(9^{\circ} 37^{\prime} 07.11^{\prime \prime N}, 76^{\circ} 23^{\prime} 04.95^{\prime \prime} \mathrm{E}\right)$, 

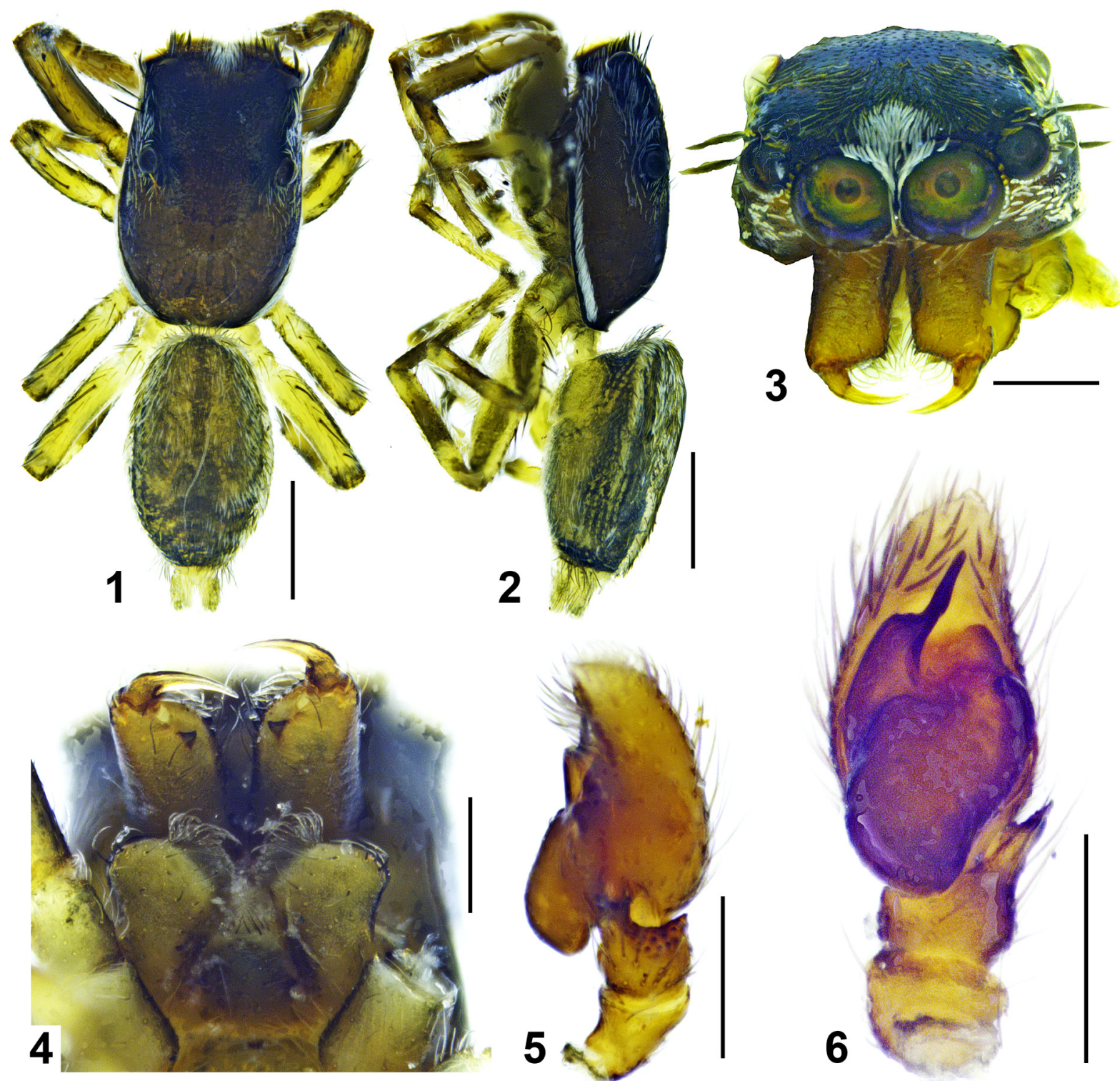

Figs 1-6. The holotype male of Icius vikrambatrai sp.n.: 1 - general appearance, dorsal view; 2 - ditto, lateral view; 3 - carapace, frontal view; 4 - chelicerae and endites, ventral view; 5 - left palp, retrolateral view; 6 - ditto, ventral view. Scale bars: $1,2(0.5 \mathrm{~mm})$; $3-6(0.2 \mathrm{~mm})$.

Рис. 1-6. Самец-голотип Icius vikrambatrai sp.n.: 1 - общий вид, дорзально; 2 - тоже, сбоку; 3 - головогрудь, спереди; 4 хелицеры и максиллы, снизу; 5 - левая пальпа, сзади-сбоку; 6 - тоже снизу. Масштаб: 1, 2 (0,5 мм); 3-6 (0,2 мм).

0 m a.s.1., from foliage, 27.02.2015, M.J. Jobi \& Jimmy Paul. Paratype: 1 ( ADSH872382), together with the holotype.

ETYMOLOGY. The specific epithet is a tribute to the Indian Kargil war hero, Captain Vikram Batra, PVC, an officer of the Indian Army. He was posthumously awarded with the Param Vir Chakra (the India's highest and most prestigious award for valour) for his tremendous actions during the 1999 Kargil War in Kashmir, for which he was also known as 'Sher Shah' ('Lion King').

DIAGNOSIS. The new species is most similar to $I$. kumariae, but it can be easily distinguished from it by the following characters: the short, stout and flattened embolus having a uniform thickness (Figs 6, 13) (embolus long, apically narrowed and bent in I. kumariae; see figs 10 and
16 in Caleb [2017]); the tri-pronged retrolateral tibial apophysis with a broad base in the male (Figs 5, 13-15) (two retrolateral tibial apophysis in I. kumariae, see figs 10-12 and 16-17 in Caleb, [2017]); a pair of prominent sclerotized pockets situated at the posterior-lateral margin of the epigyne in the female (Figs 10, 16) (bow-shaped sclerotized epigynal margin, without a visible pocket, see figs $13-15$ and 18-19 in Caleb [2017]).

DESCRIPTION. Male (the holotype, Figs 1-6). Prosoma pear-shaped, brownish, with a thin white marginal stripes of uniform thickness; anterio-lateral sides of prosoma with whitish hairs. Cephalic region blackish, with scattered pale yellowish minute setae, eyes encircled by minute orange yellowish bristles, except for one-quarter part of AMEs that 

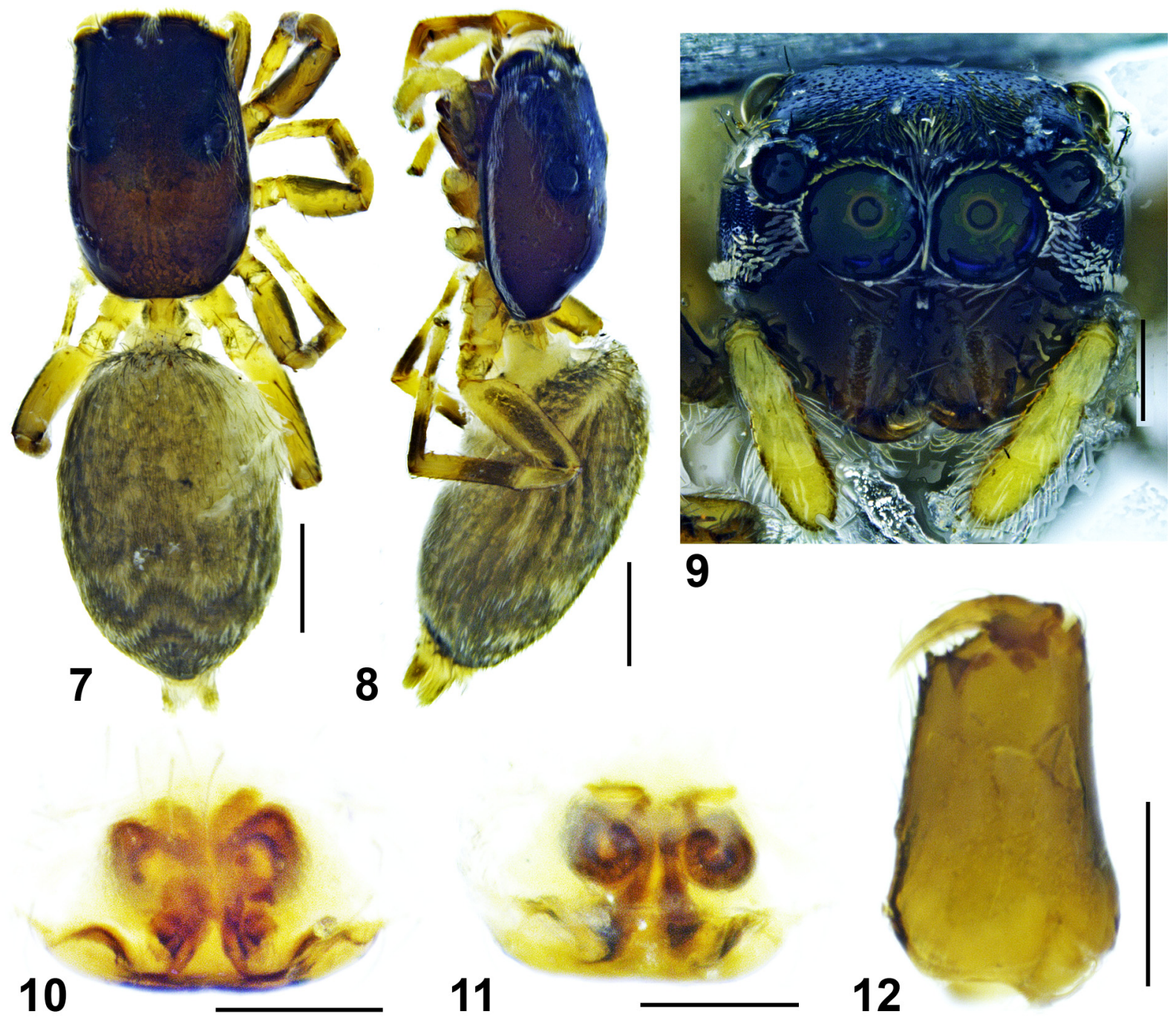

Figs 7-12. The paratype female of Icius vikrambatrai sp.n.: 7 - general appearance, dorsal view; 8 - ditto, lateral view; 9 carapace, frontal view; 10 - epigyne, ventral view; 11 - spermathecae, dorsal view; 12 - left chelicera, rear view. Scale bars: $7,8(0.5$ $\mathrm{mm}) ; 9,12(0.2 \mathrm{~mm}) ; 10,11(0.1 \mathrm{~mm})$.

Рис. 7-12. Самка-паратип Icius vikrambatrai sp.n.: 7 - общий вид, сверху; 8 - тоже, сбоку; 9 - головогрудь, спереди; 10 эпигина, снизу; 11 - сперматека, сверху; 12 - левая хелицера, сзади. Масштаб: 7, 8 (0,5 мм); 9, 12 (0,2 мм); 10, 11 (0,1 мм).

is encircled by white setae; dorsally white coloured setae making a triangle-shaped figure located anterio-medially in between AMEs (Fig. 3); anterior row of eyes with eight apical-marginal and four (two pairs) leaf-like scales behind PMEs (Fig 1-3). Clypeus, chelicerae, endites, labium and sternum brownish. Clypeus with few whitish setae. Chelicerae with two promarginal and one retromarginal teeth (which can be also visible in I. kumariae, see fig. 9 in Caleb [2017]); fangs moderate in length, yellowish brown (Fig. 4). Legs pale yellow, with apical brownish region in each segments except for brownish legs I. Opisthosoma oval, dark brownish, with several whitish setae making irregular striae at its posterior region and chevron-shaped mark anteriorly; sides dark brown, with numerous white striae and patches of blackish hairs; venter light brown (Figs 1,2). Spinnerets pale yellowish, encircled by black margin. Body length 2.16 . Prosoma length 1.18, width (at the middle) 0.77 , height (at the middle) 0.43. Opisthosoma length 0.98 , width (at the middle) 0.63 , height (at the middle) 0.53 . Eye diameter: ALE 0.11, AME 0.24, PLE 0.14, PME 0.05. Eye interdistances: AME-AME 0.01, AME-ALE 0.009, ALE-ALE 0.46, ALE-PME 0.19, PLE-PLE 0.51, PME-PME 0.59, PMEPLE 0.12. Clypeus height at ALE 0.15, at AME 0.008 . Chelicera length 0.29 . Measurements of palp and legs. Palp $0.82(0.32,0.09,0.10,0.31)$, I $1.84(0.56,0.34,0.42,0.30$, $0.22)$, II $1.44(0.46,0.24,0.31,0.25,0.18)$, III $1.55(0.48$, $0.19,0.36,0.30,0.22)$, IV $1.89(0.63,0.22,0.43,0.36$, 0.25). Leg formula: 4132. Spination. Palp: 0100, 0000, 0000, 0000; legs: femora I 0400, II 0400, III 0400, IV 0300; patellae I-IV 0000; tibiae I 1002, II 0002, III 0001, IV 0002; metatarsi I 0004, II 1001, III 1010, IV 2021; tarsi IIV 0000. Palp (Figs 5, 6, 13-15): palpal segments brownish, femur and tibia with darken blotches. Embolus stout, flattened and uniformed in thickness directed at one o'clock 

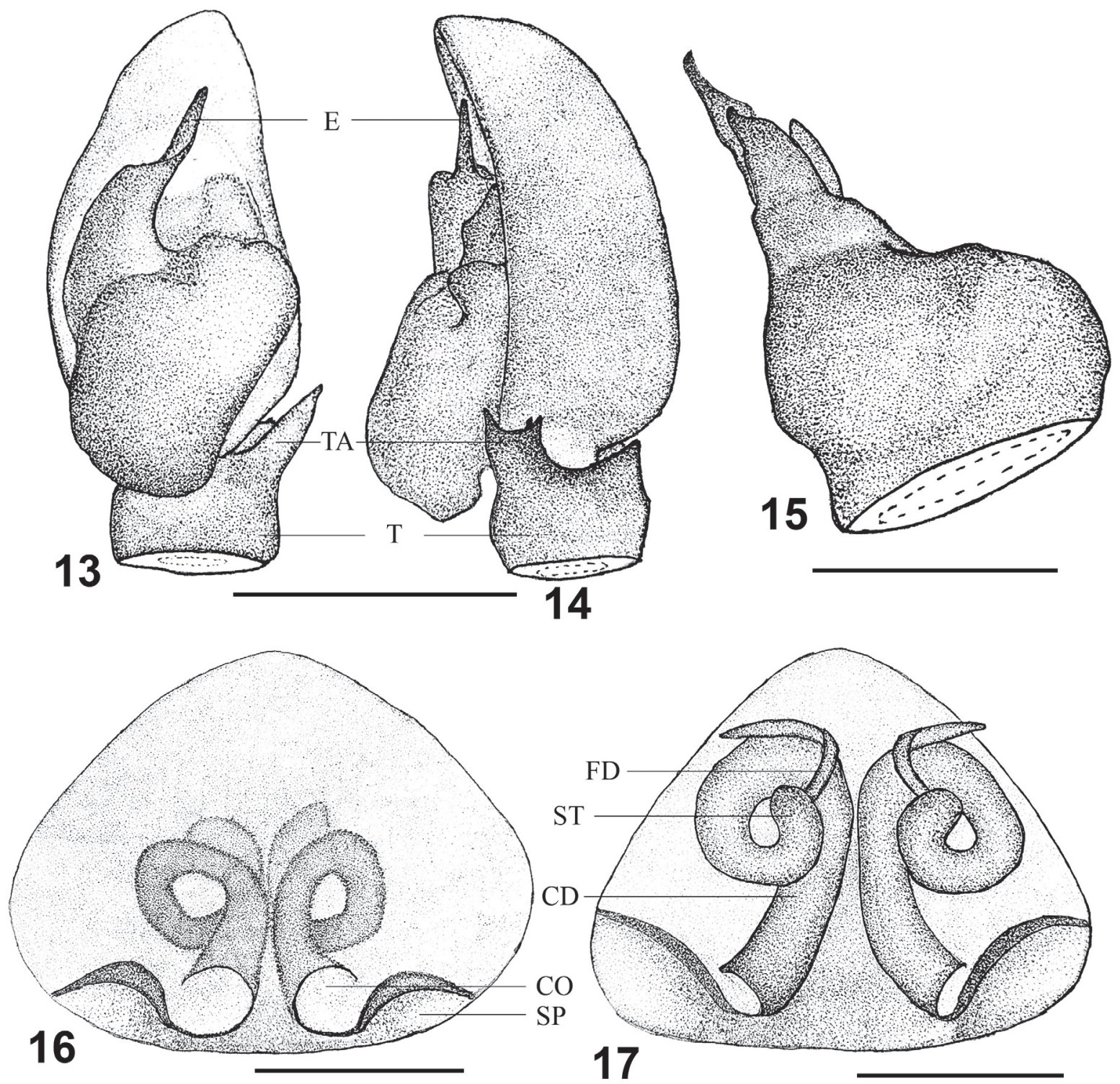

Figs 13-17. Copulatory organs of Icius vikrambatrai sp.n. ( $\sigma^{7}$ holotype and 9 paratype): 13 - left male palp, ventral view; 14 - ditto, retrolateral view; 15 - male retrolateral tibial apophysis, dorsal view; 16 - epigyne, ventral view; 17 - spermathecae, dorsal view. Scale bars: 13, $14(0.2 \mathrm{~mm}) ; 15(0.05 \mathrm{~mm}) ; 16,17(0.1 \mathrm{~mm})$. Abbreviations: CD - copulatory duct; CO — copulatory opening; E — embolus; FD - fertilization duct; SP — sclerotized pocket; ST — spermatheca; TA — retrolateral tibial apophysis.

Рис. 13-17. Копулятивные органы Icius vikrambatrai sp.n. (голотип О и паратип +): 13 - левая пальпа самца, снизу; $14-$ тоже, сбоку-сзади; 15 - тибиальный отросток пальпы самца, сверху; 16 - эпигина, снизу; 17 - сперматека, сверху. Масштаб: 13, 14 (0,2 мм); 15 (0,05 мм); 16, 17 (0,1 мм). Сокращения: $\mathrm{CD}$ - копулятивный проток; $\mathrm{CO}$ - копулятивное отверстие; $\mathrm{E}-$ эмболюс; FD - осеменительный канал; SP - склеротизированый карман; ST — сперматека; TA — ректролатеральный отросток пальпы.

position (Figs 6,13), straight spine-like appearance of the embolus is seen from the lateral view (Figs 5, 14). Retrolateral tibial apophysis tri-pronged, with a broad base; superior prong is bigger than two others (Figs 5, 14, 15). Bulb dark brownish, slightly projecting posteriorly, sperm duct is invisible externally because of the highly sclerotized bulb (Figs 5, 6).

Female (paratype, Figs 7-12, 16, 17): In all details as described for the male, except as follows: cephalic region without any leaf-like setae. Body length 2.74. Prosoma length
1.25 , width (at the middle) 0.99 , height (at the middle) 0.48 . Opisthosoma length 1.49, width (at the middle) 0.89, height (at the middle) 0.84. Eye diameter: ALE 0.11, AME 0.24, PLE 0.12, PME 0.04. Eye interdistances: AME-AME 0.01, AME-ALE 0.007, ALE-ALE 0.46, ALE-PME 0.20, PLEPLE 0.55, PME-PME 0.60, PME-PLE 0.13. Clypeus height at ALE 0.18, at AME 0.008. Chelicera length 0.27. Measurements of palp and legs. Palp $0.83(0.35,0.11,0.12$, $0.25)$, I $1.54(0.50,0.29,0.34,0.22,0.19)$, II $1.34(0.43$, $0.21,0.29,0.22,0.19)$, III $1.51(0.46,0.19,0.32,0.31$, 


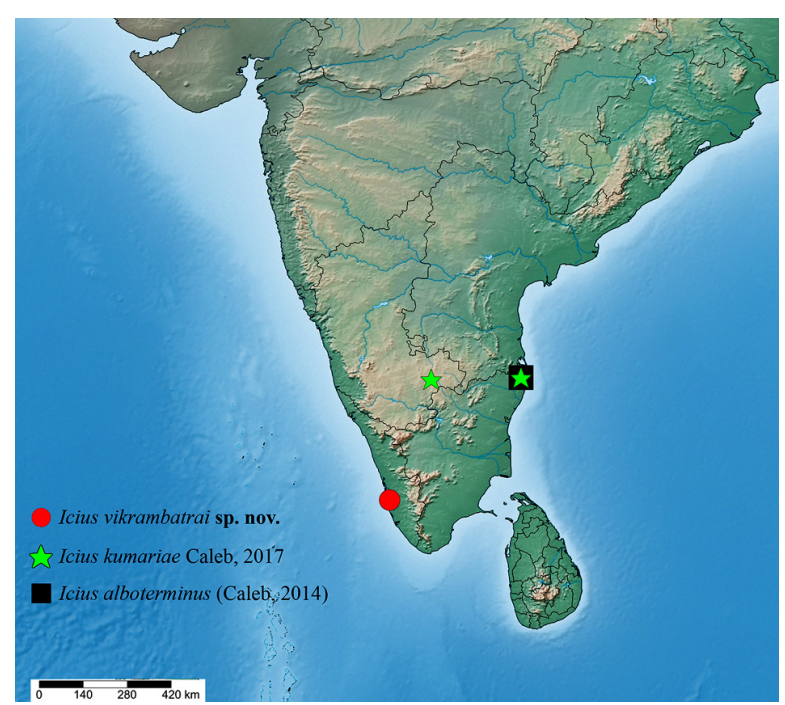

Map. Collecting localities of Icius species in India.

Карта. Точки находок видов Icius в Индии.

$0.23)$, IV $1.95(0.66,0.22,0.46,0.37,0.24)$. Leg formula: 4132. Spination. Palp: spineless; legs: femora I 0300, II 0300, III 0300, IV 0300; patellae I-IV 0000; tibiae I-IV 0001; metatarsi I 0004, II 1001, III 0001, IV 1010; tarsi IIV 0000. Epigyne (Figs 10, 11, 16, 17): epigynal plate simple, somewhat triangular, with more sclerotized posterior margin and a pair of prominent sclerotized pockets (=flaps) situated poserio-laterally. Copulatory ducts short, uniform in thickness except for being slightly broader near the copulatory openings, making a single loop apically (Figs 11, 17). Spermathecae small and simple, not reaching the height of the loop made by the copulatory ducts (Figs 11, 17) (in $I$. kumariae, the spermathecae reach the height of the loop made by copulatory ducts, see figs $13-15$ and $18-19$ in Caleb [2017]). Copulatory openings positioned posteriormedially, highly sclerotized, with their margin attaching to sclerotized pockets (Figs 11, 17). Fertilization ducts long (Figs 11, 17).

DISTRIBUTION. The type locality only: India: Kerala, Pathiramanal Island, Alappuzha (Map).

Acknowledgements. We are grateful to Rev Fr Prasanth Palackappillil CMI, Principal, Sacred Heart College, Thevara, Cochin, for providing us all the facilities used in this work. We are grateful to Dr Dmitri Logunov (Manchester, UK) for providing valuable suggestions and corrections, helping us to improve the ms. We are thankful to Miss Priyal Prajapati and Mr Jimmy Paul for their generous help at the initial stage of this work. Finally, we wish to acknowledge the Ministry of Environment, Forest \& Climate Change (MoEFCC), New Delhi, for funding support under the All India Co-ordinated Project on Capacity Building in Taxonomy: No. 22018/04/2010-CS (AICOPTAX).

\section{References}

Caleb J.T.D. 2014. A new species of Phintella Strand (Araneae: Salticidae) from India // Munis Entomology and Zoology. Vol.9. No.2. P.605-608.

Caleb J.T.D 2017. Jumping spiders of the genus Icius Simon, 1876 (Araneae: Salticidae) from India, with a description of a new species // Arthropoda Selecta. Vol.26. No.4. P.323-327. doi: 10.15298 /arthsel.26.4.07

WSC 2018. World Spider Catalog (version 18.5). Natural History Museum Bern; online at: http://wsc.nmbe.ch (accessed on 18 August 2017).

Responsible editor D.V. Logunov 